\title{
TURKISH DELIGHT \\ DOES TURKEY'S ACCESSION TO THE EU BRING ECONOMIC BENEFITS?
}

\author{
ARJAN M. LEJOUR \\ RUUD A. DE MOOIJ \\ CESIFO WORKING PAPER NO. 1183 \\ CATEgORY 7: TRADE POLICY \\ MAY 2004 \\ An electronic version of the paper may be downloaded \\ - from the SSRN website: \\ http://SSRN.com/abstract $=542402$ \\ - from the CESifo website: \\ www.CESifo.de
}




\title{
TURKISH DELIGHT DOES TURKEY'S ACCESSION TO THE EU BRING ECONOMIC BENEFITS?
}

\begin{abstract}
We explore the economic implications of the possible Turkish accession to the European Union. We focus on three main changes associated with Turkish membership: (i) accession to the internal European Market; (ii) institutional reforms in Turkey triggered by EUmembership; and (iii) migration in response to the free movement of workers. Overall, the macroeconomic implications for EU countries are small but positive. European exports increase by around 20 percent. Turkey experiences larger economic gains than the EU: consumption per capita is estimated to rise by about 4 percent as a result of accession to the internal market and free movement of labour. If Turkey would succeed in reforming its domestic institutions in response to EU-membership, consumption per capita in Turkey could raise by an additional 9 percent. These benefits would spill over to the EU.
\end{abstract}

JEL classification: F13, F15.

Keywords: Turkey, regional economic integration, general equilibrium model, gravity equations, institutional reform, migration.

Arjan M. Lejour

$C P B$

P.O.Box 80510

2508 GM, The Hague

The Netherlands

lejour@cpb.nl
Ruud A. de Mooij

$C P B$

P.O.Box 80510

2508 GM, The Hague

The Netherlands

demooij@few.eur.nl 

Introduction

These days, the possible enlargement of the European Union with Turkey is a major issue of discussion. With the accession of ten new member states in May 2004 and perhaps the subsequent accession of Bulgaria and Romania in a couple of years from now, Turkey is the thirteenth candidate member state of the EU. Unlike with Bulgaria and Romania, accession negotiations with Turkey have not yet started. At the Council in Copenhagen in December 2002, European leaders have, however, promised to decide about a starting date for the negotiations in December 2004, at the end of the Dutch Presidency. In particular, the Copenhagen Council concludes that: "If the European Council in December 2004, on the basis of a report and a recommendation from the Commission, decides that Turkey fulfils the Copenhagen political criteria, the European Union will open accession negotiations with Turkey without delay". These political criteria, formulated in Copenhagen in 1993, require a candidate country to have achieved stability of institutions guaranteeing democracy, the rule of law, human rights and respect for and protection of minorities. ${ }^{1}$

Turkey has applied for EU membership already in 1987. To pave the way for its accession, it agreed upon a Customs Union with the EU in 1995. Between 1996 and 2001, tariffs and quantitative restrictions on trade between Turkey and the EU were gradually removed.

Moreover, Turkey aligned its trade policies with the EU vis-à-vis third countries and started to implement common standards, rules and regulations. In 1999, Turkey attained the status of candidate for membership of the EU. As a result, the EU is now cooperating with Turkey to enable the adoption of the acquis communautaire, i.e. the rules and regulations that make the EU.

Despite progress in the economic integration between the EU and Turkey, a number of Europeans seem reluctant to accept Turkey as a member of the EU for a variety of reasons. For instance, people refer to the different culture of the Turkish society or the Islam religion among the majority of the population. But people also fear the economic implications of Turkey's accession to the EU. In particular, Turkey would become a net recipient of EU funds, which implies a net cost for existing member states. In addition, people in Western Europe fear massive immigration flows from Turkey and cheap imports at the cost of workers and producers in the EU.

This paper concentrates on the economic implications of the Turkish accession to the EU. Although these are not official criteria for the decision about its accession, they do play an important role in the discussion. How much will the accession of Turkey benefit or cost European producers and consumers in terms of production and welfare? Which sectors will gain and which will lose? Is there a difference between European countries?

In answering these questions, we may rely on existing studies that have assessed the economic effects of regional economic integration. In particular, a number of studies have

${ }^{1}$ At the same time economic and institutional criteria were formulated: (i) a functioning market economy and the capacity to cope with competitive pressures and market forces within the Union; and (ii) comply with the acquis communautaire. 
simulated the implications of the enlargement of the EU with the countries from Central and Eastern Europe (see De Mooij and Tang (2003) for an overview). They show that enlargement will probably yield substantial gains for the new Member States, with estimates ranging from $1.5 \%$ to $7.8 \%$ increases in GDP in the long term. For EU countries, the effects are typically more modest but still positive: the European Commission reports the largest increase in GDP of $0.4 \%$ in the long run (European Commission, 2001).

It is not a priori clear, however, that the accession of Turkey will yield similar effects as is predicted by studies for Central and Eastern Europe. Indeed, there are several differences between the accession of Turkey and that with the other countries. For instance, the EU and Turkey already form a Customs Union in manufacturing and services, and a number of standards and regulations have already been harmonised. ${ }^{2}$ Hence, the extent to which accession of Turkey to the EU will deepen the integration differs from that of the Central and Eastern European countries. Moreover, the structure of the Turkish economy differs from that of Central and Eastern European countries, e.g. with respect to its degree of openness, its sectoral structure, and its level of welfare. These differences can affect the increase in bilateral trade and GDP of further integration with the EU. In this study, we use a CGE model that incorporates the specific structure of the Turkish economy to assess the impact of its accession to the EU.

Moreover, we pay due attention to what can be expected from further steps in the integration process.

Apart from the macroeconomic implications, we also explore how Turkey's accession to the EU affects different countries in Europe and different industries. For instance, the impact on Central and Eastern European countries may differ from that on current EU member states because the former countries specialise in similar products as Turkey. With respect to the sectoral implications, the removal of economic barriers to integration may have different implications for the labour-intensive agricultural and textile sectors than for skill-intensive sectors.

In exploring these questions, the paper follows the approach of Lejour et al. (2004). For 15 different industries, we derive the potential trade between the EU and Turkey from estimating gravity equations. By comparing this potential trade with actual trade, we estimate the tariff equivalent of the remaining trade barriers between Turkey and the EU. These barriers are then removed to simulate the accession of Turkey to the EU internal market, thereby using a computable general equilibrium (CGE) model for the world economy that is calibrated on data for 2001 .

In the process of accession, Turkey has to comply with the acquis communautaire. This could act as a catalyst for improving institutions in Turkey. Many institutional indicators show that these institutions are less market-oriented in Turkey than in the EU member states or the

\footnotetext{
${ }^{2}$ The EU and the countries of Central and Eastern Europe eliminate bliateral import tariffs in manufacturing already during the 1990s. However these Europe agreements implied less trade integration than the customs union between Turkey and the EU. For instance, a customs union also involves the same external tariffs with respect to third countries.
} 
other accession countries. We investigate to what extent a reform of these institutions could benefit the Turkish economy by improving its competitive position. Again, we do this by deriving the potential trade between Turkey and other countries if the institutions would be improved by estimating a gravity equation for trade. We then simulate the macroeconomic effects of this trade increase with our CGE model.

As a final step, we elaborate on the potential migration flows following the accession of Turkey to the EU. With our CGE model, we explore the implications for labour markets.

The rest of this paper is organised as follows. Section 2 discusses the Turkish economy. Section 3 demonstrates what kind of shocks the accession of Turkey to the EU would imply. Section 4 elaborates on the main features of the WorldScan model and assesses the impact of various shocks on the economies of both the EU and Turkey. Finally, section 5 concludes.

\section{The Turkish economy}

Table 2.1 shows some key economic indicators of the Turkish economy in 2000, i.e. the year before the crisis. The table compares these indicators with the EU-15, the countries that will accede to the EU in 2004 (Accession-10), and Bulgaria and Romania. We see that Turkey is a relatively large accession country. Its size in terms of population (more than 68 million people) approaches that of the Accession-10 and exceeds the size of each current EU Member State, except for Germany. The Turkish accession would imply that the EU population would increase by more than $17 \%$.

\begin{tabular}{lrrr}
\hline Table 2.1 Key economic indicators for Turkey in 2000, compared with other regions & \\
& Population & $\begin{array}{r}\text { GDP } \\
\text { (millions) }\end{array}$ & $\begin{array}{r}\text { Per capita GNI } \\
\text { (current bln. US\$) }\end{array}$ \\
EU-15 & 376.3 & 8325 & 100 \\
Accession-10 & 75.1 & 330 & 44 \\
Bulgaria & 7.9 & 12 & 23 \\
Romania & 22.4 & 33 & 27 \\
Turkey & 68.6 & 199 & 30 \\
Source: World Bank (2003a). & & & \\
\hline
\end{tabular}

In terms of GDP, the accession of Turkey would imply a more modest expansion of the EU. Indeed, GDP would rise by $2.2 \%$ of today's level of GDP in the EU-15. The Turks thus earn a much lower income per capita than the average EU citizen. Expressed in terms of purchasing power parities, gross national income per capita in Turkey is only $30 \%$ of that in the EU-15. This income is of a similar level as in Romania and somewhat higher than in Bulgaria. It is, 
however, below the average level in the Accession-10, which is $44 \%$ of the EU-15 average in 2000. The unemployment rate in Turkey was $8.5 \%$ in $2000 .^{3}$

\section{Trade relations}

Trade liberalisation has been an important aspect of Turkey's economic policy since the early 1980's. It led to the formation of the Customs Union between Turkey and the EU in 1995 , which covers trade in industrial goods and processed agricultural products. The agreement with Turkey goes beyond a normal Customs Union, though. It also covers the harmonisation of technical legislation, the abolishment of monopolies and the protection of intellectual property. Moreover, negotiations have been started on the mutual opening of the public procurement markets, liberalisation of trade in services, and the abolition of restrictions on the freedom of establishment. These latter policies would prepare Turkey for membership of the EU.

Trade liberalisation has intensified economic integration of Turkey and the rest of the world. To illustrate, whereas the sum of imports and exports as a share of GDP was still only $18 \%$ in 1980, this share has increased to almost 50\% in 1999.

Table 2.2 shows the openness of Turkey and other accession countries in terms of their export/gdp ratio. Openness depends not only on trade policies, but also on other factors like the sectoral structure and the size of the economy. In particular, large countries are generally less open to trade than small countries. Table 2.3 shows that Turkey, being the largest country in the table, is least open. It exports slightly more than $21 \%$ of its GDP. For an average country in the EU-15, this share is almost $28 \%$ and in the Accession-10 almost 38\%. Bulgaria features a high share of more than $60 \%$. A relatively low degree of openness implies that a trade increase due to the internal market has less effect on the total economy than for countries with a higher degree of openness.

Most European countries export only a small part of all their goods and services to Turkey. Indeed, the average export share of the EU-15 to Turkey is $1.2 \%$. This share is four times smaller than for the other accession countries, which feature an average export share of around $5 \%$. An average Accession-10 country has Turkey as a destination for only $0.5 \%$ of all exports. Being neighbouring countries, Bulgaria and Romania bring $10.3 \%$ and $6.1 \%$ of their exports to Turkey, respectively. The final column of table 2.2 shows the export shares with a destination in the EU-15. We see that, similar to Accession-10 and Bulgaria and Romania, the majority of all exports from Turkey are transported to the EU-15. This reflects the agreement on the customs union between Turkey and the EU, which has intensified economic integration between these regions since 1995 .

\footnotetext{
${ }^{3}$ Note that the 2001 crisis has severely reduced the welfare level in Turkey measured in US\$. Moreover, the unemployment rate increased from $8.5 \%$ to $9.9 \%$ in 2001 .
} 
EU-15

Accession-10

Bulgaria

Romania

Turkey
62.1

Source: IMF, Directorate of Trade Statistics 2002.

Irrespective of the degree of openness, the integration of Turkey with the EU is somewhat less advanced compared to the EU-15 and the Accession-10. The reason is that various barriers to trade between Turkey and the EU-15 have maintained, despite the Customs Union. In particular, Turkey still has to take and implement measures concerning the removal of technical barriers to trade, harmonise commercial policy, align to the preferential customs regime, and abolish state monopolies and state aid. ${ }^{4}$ A part of these measures is related to the institutions in Turkey. Hence, there is room for further integration if Turkey would indeed conform to all the rules of the internal European market and is able to reform its institutions.

\section{Sectoral structure}

Table 2.3 reveals how total value added in Turkey is divided between fifteen different sectors. It shows value-added shares in percent of total value-added for Turkey, the Accession-10, Bulgaria, Romania and the EU-15. We see that the Turkish economy features a relatively large share of value added in Agriculture of $14.2 \%$. This share is smaller than that for Bulgaria and Romania, where the Agricultural sector comprises $28.2 \%$ and $19.3 \%$ of total value added, respectively. It is much larger, however, than in the Accession-10, where the Agricultural sector is responsible for $6.9 \%$ of value added, and the EU-15 where it is only $2.5 \%$. $^{5}$ One reason for the large agricultural sector in Turkey is the substantial amount of agricultural support by the Turkish government. In particular, transfers to farmers run up to 5\% of GDP. In addition, there are guaranteed output prices, import protection, export subsidies, subsidised services to farmers and sometimes state involvement in supply. Under pressure of the WTO and with the prospect of future accession to the EU, Turkish agricultural policy is now being gradually reformed. The aim is to bring it more in line with the CAP and reduce the amount of public support. The reforms may have substantial implications for the agricultural sector in Turkey in the coming years.

\footnotetext{
${ }^{4}$ At the end of 2000, the EU Embassies' Commercial Councillors in Ankara reported to Brussels several problem areas, varying from excessive bureaucracy to difficulties in applying the requirements of the Customs Union in letter and spirit. Lack of well trained civil servants is a major problem, implying that companies find it difficult to get the right information on import requirements and causing unnecessary delays. EC (2003) and Togan et al. (2003) also report that Turkey has not incorporated the instruments to remove technical barriers to trade in its legal order.

${ }^{5}$ Measured in terms of employment, the share of the Agricultural sector in Turkey is larger since productivity levels are low. Indeed, $33 \%$ of all working people is employed in Agriculture. Only in Romania, this figure is higher with a share of $45.2 \%$. In the Accession-10, $15.5 \%$ of total employment works in the Agricultural sector, while in the EU-15 this share is $4.3 \%$.
} 
Apart from Agriculture, Turkey also features relatively large Textiles, Trade Services and Transport Services sectors. ${ }^{6}$ These sectors are labour-intensive and feature relatively low productivity levels. The tourism sector is part of Trade Services and Transport Services and is important for the Turkish economy. ${ }^{7}$ Compared to the Accession-10, Turkey features a low share in Machinery and Equipment, Transport Equipment and Business Services.

\begin{tabular}{|c|c|c|c|c|c|}
\hline \multirow[t]{2}{*}{ Table 2.3} & ectors in & of total value & 2001 & & \\
\hline & Turkey & Accession-10 & Bulgaria & Romania & EU-15 \\
\hline Agriculture & 14.2 & 6.7 & 28.2 & 19.3 & 2.5 \\
\hline Energy & 3.6 & 3.2 & 4.5 & 5.3 & 1.8 \\
\hline Food processing & 6.2 & 5.6 & 9.9 & 13.8 & 3.1 \\
\hline Textiles & 2.3 & 1.0 & 3.6 & 1.5 & 0.6 \\
\hline Wearing apparel & 1.3 & 1.3 & 0.8 & 4.2 & 0.5 \\
\hline Chemicals and minerals & 3.8 & 5.6 & 8.0 & 4.6 & 4.7 \\
\hline Other manufacturing & 2.1 & 4.8 & 2.7 & 4.1 & 3.6 \\
\hline Metals & 1.3 & 1.8 & 2.5 & 1.1 & 0.9 \\
\hline Machinery and equipment & 3.2 & 8.2 & 4.4 & 5.0 & 7.7 \\
\hline Transport equipment & 1.4 & 2.4 & 0.5 & 2.4 & 2.6 \\
\hline Transport services & 11.6 & 5.7 & 5.8 & 6.8 & 4.7 \\
\hline Trade services & 20.6 & 12.7 & 4.0 & 6.2 & 12.8 \\
\hline Business services & 7.1 & 16.7 & 19.7 & 15.9 & 18.2 \\
\hline Other services & 16.9 & 18.0 & 3.4 & 3.9 & 30.6 \\
\hline Construction & 4.5 & 6.2 & 2.1 & 5.7 & 5.7 \\
\hline
\end{tabular}

\section{Export specialisation}

Table 2.4 shows the so-called revealed comparative advantages of Turkey. In particular, the first column presents the share of exports of a particular sector in Turkey, relative to the average share of that sector in other countries' export (and multiplied by 100). If a sector features an index larger than 100, then it is said that Turkey specialises its exports in that sector, i.e. it has a revealed comparative advantage in that sector relative to other countries. According to this index, table 2.5 reveals that Turkey specialises in Agriculture, Textiles, Wearing Apparel, and most Services sectors (excluding Trade Services). The exports of Textiles, Wearing Apparel,

\footnotetext{
${ }^{6}$ See Francois (2003) for an elaborate analysis of the implications of the Turkish accession to the EU for the transport sector.

${ }^{7}$ The size of the sector Trade Services is surprisingly high. The number corresponds to recent data of the Statistical Yearbook of Turkey 2001. These numbers show that the number is inflated by the size of the wholesale and retail sector. This subsector from trade services delivers $16.8 \%$ of value added in 2001 . It is possible that the Turkish Statistical Office classifies economic activities as wholesale and retail trade that are classified as business services in other countries.
} 
Transport and Business Services are also important in absolute terms: they make up more than $50 \%$ of all exports of Turkey, since these sectors are relatively open. ${ }^{8}$

The comparative advantages of Turkey to some extent mimic those from the other accession countries (see Lejour et al., 2004). In particular, both specialise in Agriculture, Textiles and Wearing Apparel. Accordingly, the accession of Turkey to the EU could affect the competitiveness of the Central and Eastern European Countries in these sectors. Yet, there are also some important differences. Most of the Accession-10 countries export more machinery products and more products from the Food Processing industry, while Turkey exports relatively more Business and Other Services.

\begin{tabular}{|c|c|c|c|}
\hline \multirow[t]{3}{*}{ Table 2.4} & \multirow{3}{*}{$\begin{array}{r}\text { Revealed Comparative } \\
\text { Advantage }\end{array}$} & \multirow{3}{*}{ Export in \% total exports } & \multirow{3}{*}{ Exports in \% of production } \\
\hline & & & \\
\hline & & & \\
\hline Agriculture & 225 & 4.5 & 7.9 \\
\hline Energy & 18 & 1.0 & 4.0 \\
\hline Food processing & 82 & 2.9 & 7.3 \\
\hline Textiles & 534 & 13.4 & 63.5 \\
\hline Wearing apparel & 403 & 9.6 & 72.9 \\
\hline Chemicals and minerals & 63 & 7.3 & 24.9 \\
\hline Other manufacturing & 52 & 3.0 & 15.8 \\
\hline Metals & 144 & 5.9 & 34.7 \\
\hline Machinery and equipment & 38 & 10.9 & 42.6 \\
\hline Transport equipment & 71 & 6.8 & 54.9 \\
\hline Transport services & 129 & 10.3 & 21.5 \\
\hline Trade services & 81 & 2.5 & 3.7 \\
\hline Business services $^{a}$ & 151 & 11.3 & 40.9 \\
\hline Other services $^{a}$ & 125 & 5.9 & 11.3 \\
\hline Construction $^{\mathrm{a}}$ & 696 & 4.6 & 16.2 \\
\hline \multicolumn{4}{|c|}{ Source: Dimaranan and McDougall (2004) and own calculations. } \\
\hline \multicolumn{4}{|c|}{$\begin{array}{l}\text { aThe ratio of exports to production in business and other services, and construction is much higher than in other countries. Given the low } \\
\text { quality of the service trade data it is not clear that these data reflect a strong international position of Turkey in these sectors. }\end{array}$} \\
\hline
\end{tabular}

\section{Turkey's accession to the EU}

\subsection{Turkey's development without accession}

How would the Turkish economy develop over the next twenty years if the country would not accede to the EU? One can imagine different scenarios. Turkey could integrate economically with the EU, without becoming a full member. In that case, the Customs Union may be further

\footnotetext{
${ }^{8}$ Not every sector in which Turkey has a comparative advantage is important for trade. Take for example Construction: Turkey has a comparative advantage in this sector, but since trade in Construction is fairly low, it does not contribute much to the openness of the Turkish economy
} 
deepened, without Turkey becoming part of the internal market. Alternatively, Turkey could become disappointed about its cooperation with the EU and decide to focus more on its relationship with its eastern neighbours in Asia. In that case, a process of disintegration with the EU may become real.

Uncertainty about the future development in the absence of accession to the EU renders it difficult to assess the economic implications of the accession itself. Against what scenario should we compare the accession? We adopt the usual approach in model simulations by developing a baseline scenario in which the current situation is extrapolated into the future. Thus, the baseline neither assumes a tendency towards disintegration, nor a tendency towards more integration. The impact of the accession to the EU is then determined by comparing the economic outcomes of a scenario with accession to the baseline.

In the next section, we follow this approach by simulating the economic implications of the Turkish accession with a CGE model called WorldScan. We develop a baseline until 2025 in which the relationship between Turkey and the EU remains as it is today, i.e. a customs union in industrial products, a limited degree of integration with respect to the internal market, but neither full membership of the EU nor further integration in other respects. In the baseline, we assume that ten candidate countries from Central and Eastern Europe become member of the EU in 2004 while Bulgaria and Romania accede in 2007. We also assume that the international agreement of textiles and clothing (ATC) vanishes in 2005 such that the Turkish textile sector will face more competition from Asian countries. With regard to Turkey, we include demographic projections based on the UN, which suggests that population grows from 68 million in 2001 to around 86 million in 2025. We do not include substantial reforms in Turkish policy as compared to today's situation. Economic growth in Turkey in the baseline scenario exceeds that in the EU due to a catching up. In particular, the baseline assumes a real growth rate of GDP of 5.6\% per year in Turkey, which is partly due to a relatively fast growing population. GDP per capita grows annually by $4.5 \% .^{9}$ In the Accession-10, growth is lower at $2.9 \%$ per year, in part because of a gradual shrinking population ( $0.3 \%$ annually). GDP in the EU is assumed to grow at $2 \%$ per year during the coming decades.

Relative to the baseline scenario, we explore the economic implications of the Turkish accession. In particular, we determine first the long-term economic outcomes in the baseline scenario and then compare them with the outcomes in a scenario with accession of Turkey. Thereby, we assume that Turkey becomes a member of the EU in 2010. The exact date, however, has no significant impact on the long-term simulation outcomes. An important question is: what effects do we attribute to the accession of Turkey. In the next subsections, we discuss four changes that are induced by Turkey's accession to the EU. These are, respectively, accession to the internal European market, an improvement of Turkish institutions in response

\footnotetext{
${ }^{9}$ Differences in total factor productivity growth rates for the manufacturing sectors in Turkey are taken from Filiztekin (2000) These data for the period 1980-1996 indicate high productivity growth in the sectors Metals and Machinery and Equipment and low productivity growth in food processing and other manufacturing. Also in Textiles and Wearing Apparel, productivity growth is lower than the average in manufacturing.
} 
to EU-membership, and free movement of labour. We do not explore the possible access of Turkey to EU funds since we find it impossible to predict the outcome of the political negotiations regarding the EU budget at the time Turkey accedes to the EU.

\subsection{Accession to the internal market}

A major economic aspect of the accession of Turkey to the EU involves the accession to the internal market. This will affect the economies of Turkey and EU members via trade, FDI, domestic investment, and so on. The focus here is on the trade effect of the internal market.

Accession to the internal market may increase trade for at least three reasons. First, administrative barriers to trade will be eliminated or at least reduced to levels comparable to those between current EU members. Here, one can think of reduced costs of passing customs at the frontier: less time delays, less formalities etc. Anecdotic evidence suggests that there is a lot to be gained here in the case of Turkey. Secondly, accession to the internal market implies a reduction in technical barriers to trade. The Single Market reduces these technical barriers by means of mutual recognition of different technical regulations, minimum requirements and harmonisation of rules and regulations. Although the customs union between Turkey and the EU has already eliminated some of these technical barriers, it appears that substantial further advances have to be made. Finally, risk and uncertainty will be mitigated by the Turkish accession to the EU. Especially political risks and macroeconomic instability may reduce substantially.

In measuring the economic implications of accession to the internal market, we follow the approach of Lejour et al. (2004). That study shows for the countries from Central and Eastern Europe that the accession to the internal market is much more important than the elimination of bilateral trade tariffs and common external tariffs as in a customs union. That conclusion and the existing customs union between Turkey and the EU in manufacturing suggest that the accession to the internal market is the relevant issue, and not the elimination of remaining tariffs and harmonisation of external tariffs. ${ }^{10}$ Lejour et al. (2004) measure the economic consequences of accession in two steps. First, they follow Bergstrand (1989) in estimating gravity equations on the industry level .These equations are specified as: ${ }^{11}$

$$
X_{i j s}=\alpha_{s} Z_{i j s}+\beta_{s} D_{i j s}^{E U}
$$

where $X_{i j s}$ stands for the $\log$ of exports from country $i$ to $j$ in industry $s$. The vector $Z_{i j s}$ contains several explanatory variables, including GDP (per capita) of the exporting and importing countries, the distance between the capitals of countries, a set of dummies, and the bilateral import and export tariffs between countries. The vector $\alpha_{s}$ contains the parameters we estimate

\footnotetext{
${ }^{10}$ Bekmez (2002) interprets full EU membership of Turkey more or less as the elimination of remaining tariffs and harmonised external tariffs. He shows that the effects of EU membership given the existing Customs Union are meagre.

${ }^{11}$ Note that the composition of sectors in this paper differs from that in Lejour et al. (2004).
} 
for each sector. The variable $D^{E U}$ is a dummy that equals unity if $i$ and $j$ are currently members of the EU and else zero.

We have estimated (1) by OLS using a cross-section of 38 countries for 2001 based on the GTAP data (Dinamaran and McDougall 2004). The estimates for fifteen different sectors are reported in table 3.1. An asterisk indicates no significance at a 5\% confidence interval. We see from table 3.1 that the distance variable is negative and significant in all industries, except for transport services. The size of the estimated coefficient is, however, notably lower for service sectors. This indicates that, if the services are tradable, distance matters less. The exporter and importer GDP coefficients are estimated precisely and are all positive. Nearly all of them are a bit lower than 1, which is standard in the literature.

Our main interest is in the estimated coefficient for the EU dummy, $D^{E U}$. For each of the 15 sectors this coefficient is reflected by $\beta_{s}$. Table 3.1 reveals that in twelve out of fifteen industries, the dummy has a positive and significant coefficient (at the 5\% confidence level). Hence, in these sectors, bilateral trade is systematically higher if two countries are both members of the EU. The dummies for Agriculture and Food Processing are among the largest. Hence, the internal market and the common agricultural policy in the EU intensify intraregional trade in these sectors. For Textiles and Wearing Apparel, we also find a high and significant dummy. The dummy for Raw Materials is negative, but insignificant. This may be due to oil being intensively traded between EU members and non-members alike. For Transport Equipment and Other Services, we also find an insignificant EU dummy. This suggests that, in these sectors, trade among EU members is not significantly more intense compared to two otherwise equivalent countries that are not both EU members. The insignificant dummies may either refer to industries where the internal market has not progressed much or where technical barriers to trade are unimportant.

In the lower part of table 3.1, we have a column reflecting the trade increase that corresponds to the estimated EU dummy. In particular, we assume that EU membership implies that the dummy would change from zero to one for bilateral trade patterns between the EU and Turkey. Thus, potential trade can be calculated as $\exp \left(\beta_{\mathrm{s}}\right)$, where $\beta_{\mathrm{s}}$ denotes the estimated coefficient for the EU dummy in (1). To illustrate, the coefficient for the EU dummy in Wearing Apparel is equal to 0.49 so that the potential trade is $\exp (0.49)=1.64$. This implies that trade after accession to the EU is 1.64 times as large as the actual trade between Turkey and EU members. The potential trade increase is therefore $64 \%$ of the current trade volume. For industries with an insignificant dummy, we assume that the dummy variable is zero. Hence, accession to the internal market is assumed to have no impact on trade. Overall, our estimates suggest a weighed average of the trade increases of $34 \%$. Hence, aggregate trade with the EU can rise by this amount if Turkey would be full member of the EU, as compared to the situation in $2001 .^{12}$

\footnotetext{
${ }^{12}$ Flam (2003) arrives at an estimate of $45 \%$ by estimating a macro gravity equation on the basis of a panel of 15 countries and for the period $1990-2000$. We adopt a cross-section approach, using bilateral trade between 38 countries for 2001.
} 


\begin{tabular}{|c|c|c|c|c|c|c|}
\hline & EU dummy & $\begin{array}{l}\text { Export GDP } \\
\text { per capita }\end{array}$ & $\begin{array}{l}\text { Importer GDP } \\
\text { per capita }\end{array}$ & Exporter GDP & Importer GDP & Distance \\
\hline Agriculture & 0.75 & -0.42 & -0.23 & 0.71 & 0.67 & -0.71 \\
\hline Business Services & 0.56 & -0.07 & 0.06 & 0.84 & 0.80 & -0.17 \\
\hline Chemicals & 0.23 & -0.16 & -0.18 & 0.61 & 0.60 & -0.38 \\
\hline Construction & $0.34^{*}$ & 0.12 & -0.31 & 0.91 & 0.87 & -1.04 \\
\hline Energy and Raw mat. & $-0.04^{\star}$ & -0.38 & -0.26 & 0.77 & 0.74 & -0.97 \\
\hline Food processing & 0.81 & -0.08 & -0.22 & 0.71 & 0.71 & -0.64 \\
\hline Machinery \& equipment & 0.16 & 0.24 & -0.17 & 0.96 & 0.86 & -1.05 \\
\hline Basic metals & 0.20 & $-0.03^{\star}$ & -0.15 & 0.73 & 0.87 & -1.13 \\
\hline Other manufacturing & 0.25 & -0.08 & -0.10 & 0.84 & 0.85 & -1.06 \\
\hline Other services & $-0.10^{*}$ & -0.19 & 0.12 & 0.89 & 0.77 & -0.21 \\
\hline Textiles & 0.58 & -0.41 & -0.35 & 0.81 & 0.72 & -0.91 \\
\hline Trade services & 0.14 & -0.24 & 0.11 & 0.81 & 0.80 & -0.05 \\
\hline Transport services & $0.81^{*}$ & -0.27 & 0.00 & 0.87 & 0.79 & $-0.24^{*}$ \\
\hline Transport equipment & $0.05^{*}$ & $-0.06^{*}$ & -0.03 & 1.02 & 0.78 & -1.04 \\
\hline \multirow[t]{2}{*}{ Wearing Apparel } & 0.49 & -0.67 & -0.05 & 0.74 & 0.74 & -0.94 \\
\hline & Export levies & Import tax & Constant & R squared & $\begin{array}{r}\text { Trade } \\
\text { increase }\end{array}$ & $\begin{array}{r}\text { Non-Tariff } \\
\text { Barrier }\end{array}$ \\
\hline Agriculture & 6.92 & 0.81 & -4.77 & 0.58 & 112.1 & 16 \\
\hline Business Services & -28.06 & 35.52 & -10.26 & 0.87 & 74.8 & 17 \\
\hline Chemicals & $-43.76^{\star}$ & 74.56 & -7.94 & 0.44 & 26.5 & 8 \\
\hline Construction & 7.49 & $-5.13^{*}$ & -3.26 & 0.81 & 41.2 & 7 \\
\hline Energy and Raw mat. & 12.81 & $2.62^{*}$ & -3.00 & 0.50 & 0 & 0 \\
\hline Food processing & $-0.76^{*}$ & $0.12^{*}$ & -5.64 & 0.62 & 123.7 & 17 \\
\hline Machinery \& equipment & $-7.97^{\star}$ & -3.60 & -3.32 & 0.82 & 17.8 & 4 \\
\hline Basic metals & 155.79 & -4.55 & -2.87 & 0.66 & 21.9 & 4 \\
\hline Other manufacturing & $1.48^{\star}$ & $-0.69^{\star}$ & -3.43 & 0.78 & 28.0 & 5 \\
\hline Other services & 13.01 & 246.89 & -11.04 & 0.80 & 0 & 0 \\
\hline Textiles & $4.73^{\star}$ & -4.42 & -3.10 & 0.69 & 77.8 & 12 \\
\hline Trade services & 75.77 & 640.44 & -11.06 & 0.84 & 15.1 & 3 \\
\hline Transport services & 18.07 & 299.09 & -10.68 & 0.81 & 124.4 & 24 \\
\hline Transport equipment & $-5.87^{\star}$ & $-0.44^{\star}$ & -4.23 & 0.70 & 0 & 0 \\
\hline Wearing Apparel & 5.27 & -1.79 & -3.30 & 0.64 & 63.8 & 10 \\
\hline
\end{tabular}

After having determined the potential trade increase per sector, the next step is to translate this into non-tariff barriers (NTBs). These are presented in the third column of table 3.1. Following the methodology of Lejour et al. (2004), we translate the potential trade increase per sector into a Samuelsonian iceberg trade-cost equivalent. We refer to this as a non-tariff barrier. In particular, we recalibrate the Armington demand functions in the model (i.e. the preference parameters in the utility functions) such that these reproduce the original trade data (while NTBs are incorporated). Abolishing the NTBs for all sectors in our CGE model (which is discussed in more detail in section 4), we arrive at the trade levels that correspond to the predictions in the second column of table 3.1. Lejour et al. (2004) describe this procedure in 
more detail. The estimated NTBs depend largely on the sector-specific Armington elasticities in the model, which measure the sensitivity of exports with respect to trade costs. The NTBs in the last column of table 3.1 can be interpreted as the trade costs associated with non-membership of Turkey in the internal market.

\subsection{Improving Turkish institutions}

It is sometimes argued that EU-membership may work as a catalyst for Turkish institutional reforms. For instance, by becoming EU-member, Turkey has to conform to all EU legislation and enforcement by the European Court of Justice. Moreover, via the method of open coordination, Turkey will regularly be assessed by the European Commission and other Member countries on its economic policies. EU-membership can thus trigger institutional reform in Turkey and reduce the widespread corruption. Today, the high level of corruption hinders economic transactions substantially. Internationally Turkey ranks low on the corruption index, as can be seen from table 3.2.

Improvements in institutions and transparency may benefit the economic development of Turkey by improving its competitive position. To illustrate, De Groot et al. (2003) estimate this impact for a wide set of countries, using a gravity estimation approach. They show that a similar law or regulatory framework as in the EU could increase bilateral trade between $12 \%$ and $18 \%$. Better quality institutions and less corruption would increase trade by $17 \%$ to $27 \%$. Although we cannot explicitly attribute the extent to what EU-membership will actually improve institutions in Turkey, it is clear that these have to be reformed in order conform to the internal EU market and the acquis communautaire. It can not be excluded that Turkey also reforms its institutions without becoming EU member, but the possible EU membership can be an extra stimulus to carry out these reforms.

\section{Table 3.1 Corruption index 2003 for a selection of countries, including their ranking}

$\begin{array}{lr}\text { 1. Finland } & 9.7\end{array}$

2. Denmark/ New Zealand $\quad 9.5$

\begin{tabular}{lr}
3. & Iceland \\
\hline 7. Canada/the & 9.4
\end{tabular}

7. Canada/ the Netherlands $r .0$

$\begin{array}{lr}\text { 10. United Kingdom } & 8.7\end{array}$

18. Germany $\quad 7.3$

25. France/Portugal $r .3$

33. Hungary $\quad 4.9$

54. Greece $\quad 4.2$

45. Poland $r .0$

64. Turkey $\quad 3.2$

102. Bangladesh $\quad 1.2$

* Degree of corruption, perceived by business people, academics and risk analysts derived from surveys. The assessment is between 0 (highly corrupt) and 10 (highly clean). Source: http://www.transparency.org/cpi/2002/cpi2002.en.html. 
By way of illustrating the importance of national institutional reform in Turkey, we have assessed the importance of corruption for trade relations. In particular, we have re-estimated our gravity equation on aggregate trade of the previous section, by including a multiplicative construct of the Transparency International Corruption Perceptions Index for the exporting and importing country in the equation. The coefficient for this index in the gravity equation measures the systematic impact of corruption on the intensity of bilateral trade between countries. The results are reported in table 3.3. It suggests a significant impact of corruption on trade. ${ }^{13}$ To get a feeling for the quantitative importance of corruption for trade, we did the following experiment. Suppose that, by improving institutions and obtaining more discipline within bureaucracies, EU-membership of Turkey would raise the TI Corruption Perceptions Index of Turkey to a level comparable with Portugal, i.e. Turkey would rise from place 64 with an index of 3.2 to place 25 with a value of 6.3. By doing so, we find that aggregate trade of Turkey would rise by 57\%. Compared to the EU-dummy for the internal market (which induces a rise in bilateral trade between Turkey and the EU of 34\%, suggesting an increase in aggregate trade of around 17\%), the impact of less corruption would be much bigger. If EU membership would indeed work as a catalyst for institutional reform, this therefore has potentially important economic implications for Turkey.

\section{EU-dummy}

Export GDP per capita

Importer GDP per capita

Exporter GDP

Importer GDP

Distance

Export levies

Import tax

Constant

Transparency

Estimated coefficient
$\begin{gathered}0.24 \\ -0.20 \\ -0.29 \\ 0.94 \\ 0.9 \\ -0.95 \\ -18.77 \\ -16.80 \\ -1.93 \\ 0.01\end{gathered}$

0.85

If EU membership is less successful as a catalyst for institutional reform, Turkey may rise less on the corruption index. Suppose for instance that it would only rise to place 33 with an index of 4.9, a level comparable to that of Hungary. In that case, aggregate trade of Turkey would still rise by $28 \%$.

\footnotetext{
${ }^{13}$ The coefficient for the EU-dummy, measuring the impact of the internal market on trade intensities, does not significantly change if we add the TI Corruption index (see appendix A). We have also estimated the gravity equation with an alternative index, the so-called heritage index, measuring the degree of economic freedom. The trade increase of using this index is of similar magnitude as with the TI Corruption index. The results are available upon request from the authors.
} 
As we did for the trade effect of the internal market, we translate the trade increase according to the gravity equation into an NTB associated with corruption. We then follow the same procedure as in section 3.2, i.e. we will simulate the gradual removal of the NTB in section 4, reflecting a gradual improvement in the degree of corruption in Turkey. ${ }^{14}$

\subsection{Free movement of labour}

Forecasting the migration effect of Turkey's accession to the EU is difficult. The same difficulty applies to the Central and Eastern European countries, however. A number of researchers have nevertheless attempted to come up with an estimate of the migration potential. These studies usually use historical immigration patterns to estimate the effect of income disparities (and other explanatory variables like unemployment or distance) on international migration. The estimates are then applied to the income differentials between the EU and the Central and Eastern European countries to obtain an estimate of the migration effect of EUenlargement. De Mooij and Tang (2003) collected twelve of such studies. The results of these studies have been extrapolated to show the long-term migration potential from ten Central and Eastern European countries to the EU-15. The long-term is interpreted as the migration effect 15 years after the accession. De Mooij and Tang arrive at a median estimate of 2.9 million migrants in the long term from ten Central and Eastern European Countries. This corresponds to a net migration of $3 \%$ of the total population in Central and Eastern Europe or, equivalently, $0.7 \%$ of the EU-15 population.

To assess the migration potential from Turkey to the EU, we can follow a similar approach. In particular, we derived the implicit migration elasticity for the income differential from De Mooij and Tang (2003). Subsequently, we apply the figures for the Turkish population, and the income differential between Turkey and the EU-15 to derive an estimate for the migration effect from Turkey. Turkish income per capita, measured in purchasing power parities, is $31 \%$ of the EU-15 average in 2000. This is somewhat below the average of the Central and Eastern European countries. We take account of demographic developments in Turkey. The Turkish population is expected to increase from 68 million in 2000 to 86 million in 2025. By substituting these figures in the equation for the migration potential, we obtain an estimate for the migration from Turkey to the EU of 2.7 million people in the long term. This equals $4 \%$ of the current Turkish population, or another $0.7 \%$ of the current population in the EU-15. ${ }^{15}$

The destination of migrants from Turkey is not expected to be proportional to the population of EU countries. In particular, the migration literature reveals that the destination of migrants primarily depends on network effects, i.e. new migrants go to places where previous migrants have settled. Table 3.4 shows how future migration flows would then be distributed across EU

\footnotetext{
${ }^{14}$ Because we do not have information on the effect of institutional changes on sectoral trade patterns, we assume that trade is affected equivalently in all sectors.

${ }^{15}$ Note that this estimate is based on historical immigration figures that do not necessarily refer to Turkish immigration. Hence, the estimate does not account for specific characteristics of Turks.
} 
countries. We see that a large share of Turkish migrants will reside in Germany (76\%), which will receive more than 2 million Turkish immigrants. France $(8 \%)$ and the Netherlands (4\%) also host a relatively large share of Turkish immigrants and will receive, respectively, 213 thousand and 107 thousand migrants.

\begin{tabular}{lrr}
\hline Table 3.4 & Expected destination of EU immigrants (in 1000), based on stocks in EU countries in 1999 \\
& In 1000 & In \% \\
Total & 2665 & 100 \\
Germany & 2025 & 76 \\
France & 213 & 8 \\
UK & 53 & 2 \\
Italy & 27 & 1 \\
The Netherlands & 107 & 4 \\
Rest of Europe & 240 & 9 \\
Source: Trends in international migration, OECD, SOPEMI 2001 for data on current destination; own calculations for expected \\
destination of Turkish migrants.
\end{tabular}

\section{Economic impact of Turkey's accession to the EU}

This section explores the economic implications of the Turkish accession to the internal market, the potential improvement in national institutions, and free movement of labour between Turkey and the EU. We do this by simulating three experiments with the WorldScan model. For these experiments, we discuss the macroeconomic effects. For the simulation of the internal market, we also analyse the sectoral implications. In addition, we perform sensitivity analysis on some important assumptions regarding the simulations. Before elaborating on the results, we first give a brief sketch of the model structure.

\subsection{The WorldScan model}

WorldScan is a computable general equilibrium model for the world economy (see CPB, 1999). The model is calibrated on the basis of the GTAP database, version 6 (Dimaranan and McDougall (2004)) with 2001 as the base year. The database allows us to distinguish between a large number of regions and sectors. In particular, the EU is divided into six regions: Germany, France, UK, the Netherlands, Italy, and Rest EU. The countries that accede to the EU in 2004 are referred to as the Accession-10. Other potential accession countries are all distinguished separately, i.e. Bulgaria, Romania, Croatia and Turkey. The rest of the world economy is divided further into four other regions, namely, the former Soviet Union, rest OECD, Middle East and North Africa and Rest of the World (ROW). For each region, we distinguish between 
fifteen sectors. These consist of Agriculture, Raw Materials and Energy, eight Manufacturing sectors and five Service sectors (see table 4.1). ${ }^{16}$

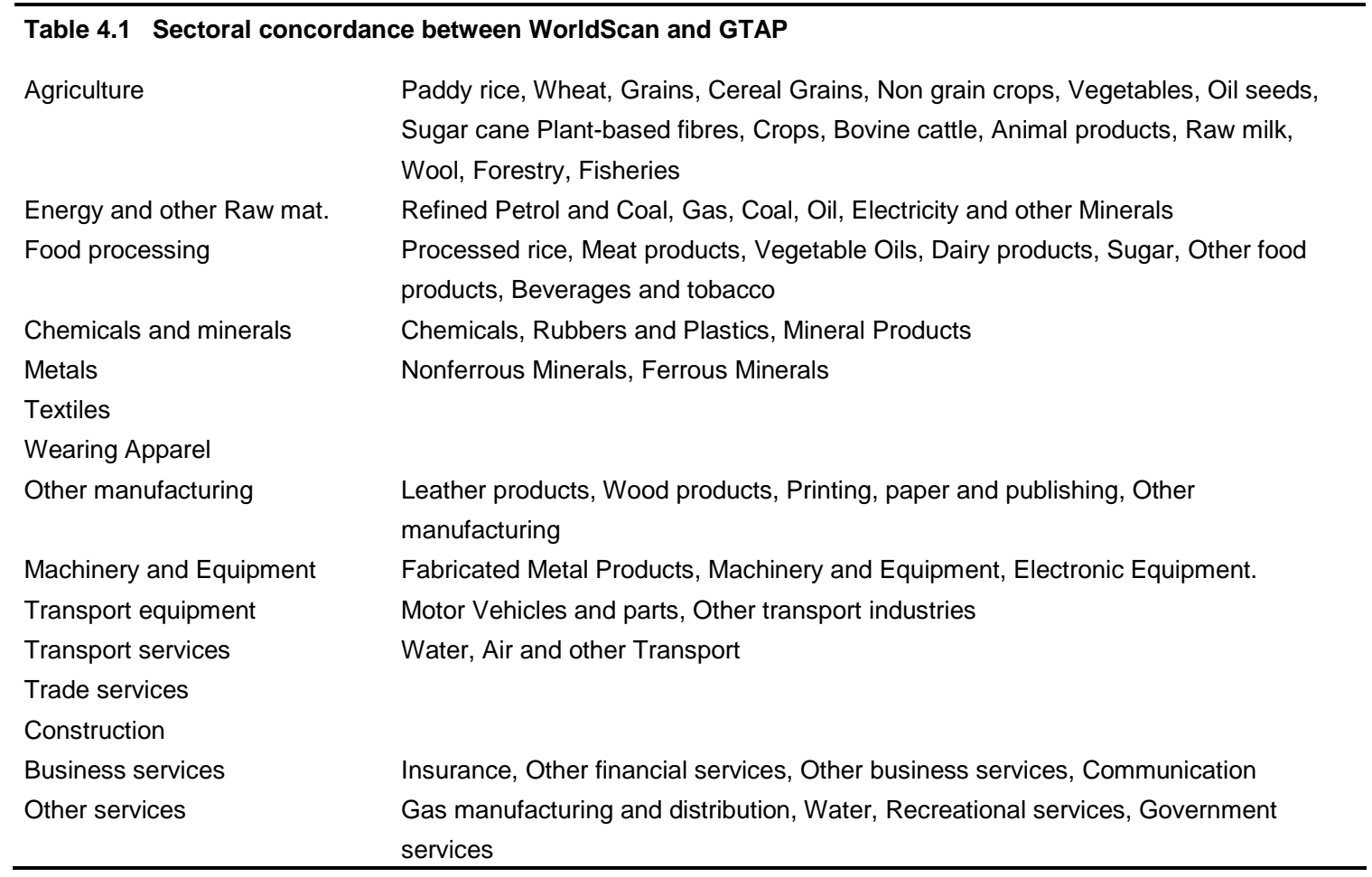

The heart of the WorldScan model relies on neoclassical theories of growth and international trade. Sectoral production technologies are modelled as nested CES functions (see table 4.2). At the highest nesting, a fixed factor is combined with a composite input. This is relevant only for the sectors agriculture and energy and other raw materials. For all manufacturing and service sectors we assume constant returns to scale in production. In the second level of the production tree, value-added plus energy inputs are combined to form a composite input into production. This CES-function has a low substitution elasticity (.01), creating a Leontief structure. The production of value-added is modelled by means of a Cobb-Douglas technology with low and high-skilled labour and capital as inputs. In principle, there are fifteen intermediate inputs. However, only a few intermediate inputs are important in the production process for most industries.

\footnotetext{
${ }^{16}$ As the model distinguishes only one aggregated agricultural sector, we are unable to explore the details of changes in the common agricultural policies of the EU.
} 
Table 4.2 Sectoral production elasticities

\begin{tabular}{lrrr} 
& All sectors & Agriculture & Energy and other raw materials \\
Fixed factor and rest & 0.10 & 0.90 & 0.20 \\
Nest of intermediates and nest of & & & \\
value added/energy & 0.01 & 0.30 & 0.01 \\
Energy and value added & 0.50 & 0.60 & 0.10 \\
Capital and labour & 1.00 & 1.00 & 1.00 \\
Intermediates & 0.60 & 0.60 & 0.60 \\
\hline
\end{tabular}

With respect to trade, WorldScan adopts an Armington specification, explaining two-way trade between regions and allowing market power of each region. The demand elasticity for manufacturing industries, agriculture and raw materials is set at 5.6, based on the work of Hummels (1999). For services, the elasticity is set at a lower level: 4.0. Bilateral trade depends on consumer preferences for regional varieties of a good, and differences in relative prices. On the capital market, WorldScan assumes imperfect capital mobility across borders. In particular, capital that is abundant in one region (and thus is relatively inexpensive), it is invested in another region in which capital is scarce (capital is expensive).

Due to barriers in investing abroad interest rate differentials are only reduced but not eliminated. Consumption patterns may differ across countries and depend on per capita income. We assume that the labour markets for low-and high-skilled workers clear. In the baseline, labour does not migrate.

Although WorldScan is rather comprehensive in describing trade relations and contains a detailed description of countries and sectors, it does not capture some economic mechanisms that are potentially important in light of the enlargement of the EU. For instance, the model does not include economies of scale. Economic integration may thus yield additional efficiency gains through better exploiting these potential scale effects. Moreover, WorldScan does not capture technology and knowledge spillovers, associated with increasing trade intensity between Turkey and the EU. Such spillovers, as well as other dynamic gains from economic integration, may yield additional benefits. They are, however, difficult to quantify and therefore not captured in our model. The simulations thus only capture the static allocative efficiency gains from EU accession.

As discussed in section 3.1, the baseline scenario of WorldScan includes developments that can be foreseen, such as demographic projections, a gradual catching up process of Turkey, the EU-accession of the other candidate member states, and the completion of the textiles and clothing agreement in 2005. Uncertain political changes are not included in the baseline. We assess the implications of EU-accession by running successively three alternative scenarios in which we impose (i) the removal of non-tariff barriers; (ii) an improvement in the institutions; and (iii) migration flows from Turkey to the EU. By comparing the outcomes of the alternative scenarios with the baseline, we obtain the impact of the Turkish accession on the economies of the EU, the other accession countries, and Turkey. In the experiments, we assume that Turkey 
enters the EU in 2010. The shocks are implemented gradually and the effects are evaluated in the year 2025 in which a new stable equilibrium is achieved.

\section{Accession of Turkey to the internal market}

We now discuss the simulation results of the Turkish accession to the internal market. In particular, we simulate a gradual abolishment of the NTBs presented in table 3.1. This removal of NTBs changes relative prices, exerts trade creation and trade diversion, changes the terms-oftrade and affects the incentives to invest. The macroeconomic and sectoral implications are presented in tables 4.3 and 4.4 .

\section{Macroeconomic effects}

Table 4.3 presents the macroeconomic effects of Turkey's accession to the internal market. We see that GDP and consumption in Turkey increase by $0.8 \%$ and $1.4 \%$, respectively. ${ }^{17}$ Welfare, measured by the equivalent variation (i.e. a measure for the rise in real private income) increases by 4.4 billion US\$ in constant prices. For the EU-15, the economic effects are small. Welfare raises by 3.8 billion US\$; expressed in percentage changes of GDP and consumption, this increase is not visible. Dutch exports to Turkey increase by around $20 \%$, while imports grow by $25 \%$. In terms of aggregate trade, this is an increase of some $0.2 \%$. The Accession- 10 countries also experience no significant impact on GDP, but an increase in consumption of $0.2 \%$.

These effects are the result of two main mechanisms. First, changes in the relative prices imply that countries can better exploit their comparative advantages. This causes trade creation, increases production efficiency and raises welfare. At the same, however, integration with Turkey causes trade diversion. Indeed, the rising imports from Turkey by a number of EU countries come at the expense of imports from other countries, primarily other accession countries that specialise in the same products. With the removal of NTBs with Turkey, these other accession countries no longer receive preferential treatment relative to Turkey and therefore face fiercer competition on the internal market. As a result, the gains for Turkey partly come at the expense of a loss in output in the Central and Eastern European countries. These effects are, however, small in macroeconomic terms.

A second effect of the accession of Turkey to the EU is a terms-of-trade effect. ${ }^{18}$ In particular, we see that Turkey experiences a terms-of-trade gain of 3.5\%. This is not accompanied by a terms-of-trade loss in other European countries: the EU-15 experience a terms-of-trade gain of $0.1 \%$ and the Accession- 10 of $0.2 \%$. The reason for the presence of terms-of-trade gains on both sides is that the abolishment of NTBs entails a reduction in real trade costs. As we measure the terms of trade as the price of exports relative to imports that

\footnotetext{
${ }^{17}$ This result is comparable to the effect of the customs union. Harrison et al. (1997) estimate a GDP gain of $1.0 \%$ to $1.5 \%$. ${ }^{18}$ Notice that his effect is not a traditional terms-of-trade effect, but the result of a change in transaction costs, modelled by a change in the Samuelsonian iceberg costs.
} 
holds just outside the domestic border, lower NTBs can raise the price of exports relative to imports in both countries. ${ }^{19}$ The different magnitude in the terms-of-trade effect among countries depends on the trade intensity between that country and Turkey. In particular, the export share of the Accession-10 and the EU-15 to Turkey is rather small, while the corresponding share of Turkish exports to the EU is relatively large. This explains the large terms-of-trade effect for Turkey relative to the other regions.

We can compare the effects in table 4.3 with those found by Lejour et al. (2004) for the Central and Eastern European countries. These simulations were also performed with the WorldScan model. The comparison reveals that the effects for Turkey are relatively small. Indeed, the enlargement of the EU with the Central and Eastern European countries yields an average increase in GDP by $5.3 \%$ for the accession countries, while consumption increases by almost $10 \%$. For the Turkish accession, the corresponding figures are $0.8 \%$ and $1.4 \%$. The reason for this difference is fourfold. First, we have re-estimated our gravity equations on the basis of more recent data for 2001. The new estimations suggest an aggregate trade increase for bilateral trade with Turkey of $34 \%$. This is about one third smaller than the increase of more than $50 \%$ for the CEEC countries that was suggested by the previous estimate (which was based on data for 1997). Secondly, Turkey is less open to European trade than an average country from Central and Eastern Europe. Thus, the country benefits less from access to the internal market. This is reinforced by the relatively small share of trade with EU-countries, relative to the Central and Eastern European countries. Thirdly, Turkey specialises in sectors for which we find relatively small effects for the internal-market dummy. For instance, we do not obtain a significant NTB for Transport Services, a sector that is relatively important for the Turkish economy. We do have a large NTB in the sector Trade Services which is very important in Turkey. However trade in that sector is low and the trade increase has no substantial effect on production in that sector. Finally, the exports of Turkey primarily involve sectors with a low productivity such as agriculture and textiles. Although these sectors benefit substantially (see below), this does not create big effects on value added and consumption.

Total exports of Turkey rise by $8.1 \%$ and imports by $12.2 \%$. This is less than expected based on the gravity equation. According to the latter method aggregate trade would rise by about $17 \%$. There are several reasons for this difference. First, there is also trade diversion. Increased trade with the EU leads to less trade with other countries. This reduces the increase in total trade. Secondly, Turkey also needs (skilled) labour, capital and intermediate inputs, such as machinery and equipment, for production. These inputs are scarce. This reduces the trade potential. The predictions of the gravity equation do not take account of these general equilibrium effects.

\footnotetext{
${ }^{19}$ For imports, the price includes cost of freight (the iceberg costs and the c.i.f - inclusive of cost, insurance and freight - that are present in the database) but not import taxes. For exports the price is f.o.b (free on board) and includes export taxes but excludes the iceberg costs.
} 


\begin{tabular}{|c|c|c|c|c|c|}
\hline \multirow[t]{3}{*}{ Table 4.3} & \multicolumn{5}{|c|}{ Macroeconomic effects of Turkey's accession to the internal market in 2025} \\
\hline & Volume of GDP & $\begin{array}{c}\text { Volume of } \\
\text { consumption }\end{array}$ & $\begin{array}{r}\text { Equivalent } \\
\text { Variation (billion }\end{array}$ & Export volume & Terms of trade \\
\hline & $(\%)$ & $(\%)$ & US\$) & $(\%)$ & (\%) \\
\hline Turkey & 0.8 & 1.4 & 4.4 & 8.1 & 3.5 \\
\hline Accession-10 & 0.0 & 0.2 & 0.1 & 0.3 & 0.2 \\
\hline Bulgaria & -0.0 & 0.1 & 0.3 & 1.3 & 0.1 \\
\hline Romania & 0.0 & 0.2 & 0.0 & 0.8 & 0.2 \\
\hline EU-15 & 0.0 & 0.0 & 3.8 & 0.2 & 0.1 \\
\hline Germany & 0.0 & 0.0 & 1.2 & 0.3 & 0.1 \\
\hline The Netherlands & -0.0 & 0.0 & 0.2 & 0.2 & 0.1 \\
\hline
\end{tabular}

The welfare gains of 3.8 billion US\$ for the EU countries are negligible related to the total size of the economy. They remain positive, however, as most EU countries suffer only marginally from trade diversion, while they benefit from trade creation. In terms of consumption, the gains are larger tan in terms of GDP because the reduction in NTBs makes imports cheaper. Still, we do not observe these positive effects in the table as the effects remain small. The reason for these small effects is that Turkey is currently a rather unimportant trade partner for the EU. Reducing NTBs will raise exports for an average EU country by $0.2 \%$. This increase, however, has no visible effect on GDP in one-digit figures.

\section{Sectoral effects}

To understand the sectoral effects of the Turkish accession to the internal market, two shocks in each sector are important. First, an industry where an NTB is abolished faces fiercer competition on the home market as the relative price of varieties from the EU falls relative to domestic varieties. This causes a shift in consumer demand away from domestic varieties, leading to higher import intensity. The drop in demand for domestically-produced commodities lowers the producer price which causes a shift in resources away from the sector where the NTB is abolished. The second shock of the removal of NTBs is that the EU lowers its tariffs. This reduces the relative consumer price of Turkish varieties in the EU, causing a higher demand for these varieties. This exerts an upward effect on the Turkish producer price which attracts resources to this sector.

The net effect is increased specialisation. On balance, a sector is likely to expand if a (large) NTB is abolished and if that sector exports a large share of its production towards the EU. If a sector produces primarily for the home market, cheaper varieties from the EU may render the impact on production in that sector negative.

In addition to the two demand effects above, the removal of NTBs also exerts a supply effect. This is because the reduction in real trade costs changes input prices for two reasons. First, lower real trade costs reduce the price of intermediate inputs so that production costs fall. Second, production costs might also change by changes in relative factor prices. 
How all these forces work out in the model depends on the details of the input-output structure, comparative advantages and the trade intensity of sectors. The model consistently links these elements and shows how the various shocks and mechanisms ultimately affect the output structure. The results are presented in table 4.2. It reveals that Textiles and Wearing Apparel expand most. The expansion is the result of their strong export orientation and the relatively large NTB that is abolished. To illustrate, one quarter of Turkish exports is from these two sectors (but only $3.6 \%$ of value added is produced here). Hence, the effect of increased access to the EU market dominates the effect of cheaper EU products on the Turkish market. Also other sectors in Turkey gain. In particular, table 4.4 shows modest increases in Trade Services and Construction. Production in 8 sectors declines, most substantially in Chemicals, Metals and Transport Equipment. These are sectors where accession to the internal market does not affect trade costs much.

\begin{tabular}{|c|c|c|c|c|c|}
\hline \multirow[t]{2}{*}{ Table 4.4} & $\begin{array}{l}\text { Turkey' } \\
\text { tive cha }\end{array}$ & $\begin{array}{l}\text { ssion to th } \\
\text { productio }\end{array}$ & nal market & 2025 & \multirow[b]{2}{*}{ EU-15 } \\
\hline & Turkey & Bulgaria & Romania & Accession-10 & \\
\hline Agriculture & 4.9 & -1.0 & -0.3 & -1.1 & -1.0 \\
\hline Energy & -0.1 & 0 & -0.0 & 0.1 & 0.0 \\
\hline Food processing & -0.2 & 0.1 & 0.6 & 0.0 & 0.1 \\
\hline Textiles & 17.8 & -1.0 & -0.3 & -0.2 & -0.4 \\
\hline Wearing apparel & 14.6 & -0.8 & -0.2 & -0.2 & -0.3 \\
\hline Chemicals and minerals & -3.9 & 0.1 & 0.2 & 1.4 & 0.2 \\
\hline Other manufacturing & 0.4 & 0.2 & 0.2 & 0.6 & 0.0 \\
\hline Metals & -0.8 & 0.2 & 0.6 & 2.1 & 0.2 \\
\hline Machinery and equipment & 2.1 & 0.1 & -0.1 & 0.4 & 0.0 \\
\hline Transport equipment & -0.9 & 0.1 & 0.2 & 0.5 & 0.1 \\
\hline Transport services & -0.6 & 0.1 & 0.2 & 0.5 & 0.0 \\
\hline Trade services & 1.0 & -0.0 & 0.2 & -0.0 & -0.0 \\
\hline Business services & -0.3 & 0.0 & 0.2 & 0.0 & -0.0 \\
\hline Other services & -0.7 & 0.0 & 0.2 & 0.2 & 0.0 \\
\hline Construction & 1.2 & -0.0 & 0.2 & 0.0 & 0.0 \\
\hline
\end{tabular}

The expanding sectors in Turkey come at the expense of the position of industries in the EU-15 and the other accession countries. Indeed, Agriculture, Textiles and Wearing Apparel contract in the EU-15, the Accession-10, Bulgaria and Romania. Workers thus shift from these sectors towards other industries which show a corresponding increase such as Chemicals, Metals and Transport Equipment.

\subsection{Institutional reform}

The second effect of the Turkish accession to the EU involves the potential improvement in national Turkish institutions. Indeed, to the extent that EU-membership triggers reforms, it can 
have important implications for the Turkish economy. We simulate institutional reforms by an improvement in the Turkish position on the TI Corruption Perceptions Index from place 64 to 25. This implies an improvement in the competitive position of Turkey, as found by the estimations of the gravity equation of section 3.3: aggregate trade increases by $57 \%$. Table 4.5 shows the macroeconomic implications of removing the corresponding NTB, which measures the trade barrier associated with the poor position of Turkey on the Corruption ladder.

\begin{tabular}{|c|c|c|c|c|c|}
\hline \multirow[t]{3}{*}{ Table 4.5} & \multicolumn{5}{|c|}{ Macroeconomic effects of a higher TI Corruption Perceptions Index for Turkey in 2025} \\
\hline & Volume of GDP & $\begin{array}{r}\text { Volume of } \\
\text { consumption }\end{array}$ & $\begin{array}{c}\text { Equivalent } \\
\text { Variation }\end{array}$ & Export Volume & Terms of trade \\
\hline & $(\%)$ & $(\%)$ & (billion US\$) & $(\%)$ & (\%) \\
\hline Turkey & 5.6 & 8.9 & 28.2 & 45.3 & 13.0 \\
\hline Accession-10 & 0.0 & 0.4 & 0.2 & 0.4 & 0.7 \\
\hline Bulgaria & -0.0 & 0.1 & 0.5 & 3.7 & 0.1 \\
\hline Romania & -0.0 & 1.1 & 0.2 & 1.2 & 1.3 \\
\hline EU-15 & -0.0 & 0.1 & 8.5 & 0.5 & 0.3 \\
\hline Germany & -0.0 & 0.1 & 2.1 & 0.5 & 0.3 \\
\hline The Netherlands & 0.0 & 0.1 & 0.6 & 0.3 & 0.2 \\
\hline Rest of world & -0.0 & 0.0 & 8.7 & 0.2 & 0.2 \\
\hline
\end{tabular}

From table 4.5, we see that an improvement in institutions raises GDP in Turkey by $5.6 \%$, while consumption rises by $8.9 \%$. Welfare increases by 28.2 billion US\$ in constant prices. These macroeconomic effects are substantially larger than the impact of the accession to the internal market. This is because of several reasons. First, the estimated trade impact of the improvement in the Corruption Index is bigger than that of the accession to the internal market. Indeed, the aggregate trade increase is more than three times larger. Second, the improvement in institutions affects all sectors alike, including the sectors metals and machinery and equipment. This contrasts the simulation for the internal market where these sectors are affected relatively mildly. The strong reduction in the user price of these capital goods is important for the economic implications, as lower capital costs encourage investments and exert an acceleration of GDP growth.

Other countries benefit from the improvements in Turkey's institutions. The biggest gain is in Romania, where consumption rises by $1.1 \%$, primarily because of cheaper imports from Turkey. The equivalent variation suggests that the EU-15 experiences a welfare gain equivalent to $\$ 8.5$ billion. Real private income in the Netherlands expands by $\$ 0.6 \mathrm{bln}$. Dutch exports to Turkey grow by more than $50 \%$ by some US $\$ 2,3$ billion. This amounts to more than $0.3 \%$ of aggregate Dutch exports.

Although the institutional improvement potentially has an important economic impact for Turkey, these gains will only materialise if the accession of Turkey to the EU will indeed induce such improvement. In case the reforms are less fundamental, the Turkish position on the 
TI Corruption Perceptions Index ladder improves less. To illustrate, if Turkey climbs up to place 33 , the level Hungary, aggregate trade will increase by $28 \%$. In that case, welfare in Turkey increases by 11 billion US\$, GDP by $2.3 \%$ and consumption by $3.5 \%$.

\subsection{Free movement of labour}

Turkish accession to the EU may also induce migration. Assuming that 2.7 million Turks will migrate after the accession (see section 3.4), we assess the economic implications by using the WorldScan model. Borjas (1999) argues that the economic impact for the countries of destination and the countries of origin typically depends on the skill level of the immigrants. We do not know the skills of the immigrants in advance: they can be either skilled, e.g. because educated people are more willing to migrate, or unskilled, e.g. because a restructuring of the agricultural sector in Turkey worsens the economic prospects in Turkey for the unskilled. To cope with this uncertainty, we perform two simulations. In the first simulation, we assume that the composition of Turkish immigrants is equal to the composition of workers in the EU (table 4.6). In a second simulation, we assume the all Turkish immigrants are unskilled. The two simulations thus provide a range for the likely economic consequences of the assumed immigration flow of 2.7 million Turks.

Table 4.6 shows that migration reduces overall GDP in Turkey by $2.2 \%$. In Germany, GDP increases by $2.2 \%$ while GDP in the Netherlands expands by $0.6 \%$. As the decline in GDP is smaller than the outflow of people from Turkey, GDP per capita rises in Turkey. The reason for this is that capital is not perfectly mobile across countries. Hence, the lower supply of labour increases the capital/labour ratio in Turkey. This raises the marginal product of labour and thereby raises wages. For similar reasons, GDP per capita in Germany and the Rest of the EU decrease. Indeed, the lower capital/labour ratio causes a decline in the productivity of labour in these countries and thus a fall in wages. The effect remains small, though, because of the modest increase in the population size. On average, GDP per capita in the falls only marginally (not visible in one-digit figures). The effect on ratio between the wage rate of unskilled and skilled workers is negligible because we assumed that the composition of migrants is identical to that of the destination country.

The effects on consumption per capita suggest a more favourable picture for Turkey and less favourable for the EU-15 than the figures for GDP per capita suggest. This is for two reasons. First, there are changes in the terms-of-trade. In particular, lower wages in the EU-15 exert a downward pressure on producer prices. The opposite holds for Turkey. This renders the terms of trade effect positive for the Turkey and negative for the EU countries. Accordingly, consumption in Turkey expands and in the EU contracts. Second, we assume that the Turkish migrants transfer part of their income to their families in Turkey. Indeed, as figure 2.5 suggests, Turks provide substantial remittances to their home country. Assuming that future Turkish migrants in Europe will also remit part of their income to their home country, consumption in the EU falls while it increases in Turkey. 


\begin{tabular}{lrrrrrr}
\hline Table 4.6 & \multicolumn{6}{c}{ Economic effects in 2025 of migration from Turkey (same skill composition as in EU-15) } \\
& $\begin{array}{l}\text { Population } \\
\text { Volume of GDP }\end{array}$ & GDP per capita & Consumption & Capital & Wage ratio \\
& $(\%)$ & $(\%)$ & $(\%)$ & per capita (\%) & stock (\%) & unskilled/skilled \\
Turkey & -3.1 & -2.2 & 0.9 & 2.5 & -1.2 & 0.1 \\
EU-15 & 0.7 & 0.7 & -0.0 & -0.2 & 0.4 & 0.0 \\
Germany & 2.4 & 2.2 & -0.1 & -0.8 & 1.2 & 0.0 \\
The Netherlands & 0.6 & 0.6 & -0.0 & -0.2 & 0.2 & 0.0 \\
Source: WorldScan simulations. & & & & & \\
\hline
\end{tabular}

The effects of migration in the EU and Turkey are different if all migrants are unskilled (see table 4.7). Migration now changes the skill composition in Turkey and the EU. The relatively higher supply of skilled workers in Turkey exerts an upward pressure on the average wage and income per capita, as compared to table 4.6. The relative scarcity of unskilled workers also increases their wage, relative to that of skilled workers by $2.5 \%$ points (see the wage ratio). Consumption and GDP per capita increase by an additional $0.5 \%$ as compared to the case of table 4.6. In the EU, the wage of unskilled workers declines relative to that of skilled workers. For Germany, the decline is $3 \%$, while in the Netherlands it is $0.7 \%$. GDP and consumption per capita decline a bit more if all immigrants are unskilled. The effects for the EU-15 remain fairly small in macroeconomic terms.

\begin{tabular}{|c|c|c|c|c|c|c|}
\hline \multirow[t]{2}{*}{ Table 4.7} & \multicolumn{6}{|c|}{ Economic effects in 2025 of migration from Turkey (all migrants unskilled) } \\
\hline & $\begin{array}{r}\text { Population } \\
(\%)\end{array}$ & $\begin{array}{l}\text { Volume of } \\
\text { GDP (\%) }\end{array}$ & $\begin{array}{r}\text { GDP per } \\
\text { capita (\%) }\end{array}$ & $\begin{array}{l}\text { Consumption } \\
\text { per capita (\%) }\end{array}$ & $\begin{array}{r}\text { Capital stock } \\
(\%)\end{array}$ & Wage ratio \\
\hline Turkey & -3.1 & -1.8 & 1.4 & 3.0 & -1.1 & 2.5 \\
\hline EU-15 & 0.7 & 0.5 & -0.1 & -0.3 & 0.5 & -0.9 \\
\hline Germany & 2.4 & 1.8 & -0.6 & -1.2 & 1.7 & -3.0 \\
\hline The Netherlands & 0.6 & 0.5 & -0.1 & -0.3 & 0.4 & -0.7 \\
\hline
\end{tabular}

\section{$5 \quad$ Conclusions}

We assess the economic effects of three shocks induced by the accession of Turkey to the EU: accession to the internal market; an improvement in national institutions in Turkey; and free movement of labour. We thus ignore the potential membership of EMU or the implications of transfers from the EU budget. Moreover, we concentrate on the long-term implications of the Turkish accession to the EU, not to short-term issues, and focus on trade relations, not to foreign direct investment.

In analysing these aspects of the Turkish accession, we first derive a quantitative measure for the potential size of the shocks of the enlargement. Then, these shocks are simulated by means of a CGE model for the world economy. The simulations yield the following results. 
The accession to the internal market yields positive effects for Turkey: private income (a measure for welfare) increases by 4.4 billion US\$ (approximately $€ 3.5$ billion, assuming $1 €=$ 1.25US\$), while GDP expands by about $0.8 \%$ in the long term. Also the current EU-15 and the countries of Central and Eastern Europe benefit from the accession of Turkey to the EU, albeit only marginally. The largest impact in Turkey is apparent in the sectors Textiles and Wearing Apparel, which expand by respectively $18 \%$ and $15 \%$. This comes at the expense of production of these sectors in Southern Europe and Central and Eastern Europe.

The effects of accession to the internal market are small compared to the potential gains of improvements in national institutions in Turkey. Indeed, if EU membership would be able to trigger reforms in Turkey such that the country would climb on the so-called Transparency International Corruption Perceptions Index to a position comparable to Portugal, our analysis reveals that welfare could increase by 28.2 billion US\$ (or $€ 22.5$ billion) while Turkish GDP would expand by 5.6\%. These effects are large, relative to the impact of the accession to the internal market. Also the EU benefits from the improvement in national Turkish institutions.

Migration involves a third effect that is potentially important in light of the accession of Turkey to the EU. An expected inflow of 2.7 million Turks would reduce GDP in Turkey by between $1.8 \%$ and $2.2 \%$, and increase it in the EU-15 by between $0.5 \%$ and $0.7 \%$, depending on the skill composition of the migrants. In per capita terms, income in Turkey will rise while it falls slightly in the EU. If migrants are primarily unskilled, also wage inequality in the EU-15 is likely to rise.

Summing up, accession of Turkey to the EU will bring economic benefits for Turkey, without exerting a big effect on current member countries of the EU or the countries from Central and Eastern Europe. Some sectors in Turkey will expand substantially, such as Textiles, but at the expense of these sectors in Central and Eastern Europe. The largest economic gains can probably be obtained through reforms of national institutions in Turkey that improve the functioning of the public sector and provide transparency to investors and traders.

\section{References}

Akgunduz, A., 2000, Turkije en internationale migratie sinds 1923, Justitiele Verkenningen nr. 8.

Bekmez, S., 2002, Sectoral Impacts of Turkish Accession to the European Union, Eastern European Economics 40, p. 57-84.

Bergstrand, J.H., 1989, The generalized gravity equation, monopolistic competition and the factor-proportions theory of international trade, Review of Economics and statistics 71, p. 143153. 
Borjas, G.J, 1999, The economic analysis of immigration, in: O. Ashenfelter and D. Card (eds.)

Handbook of Labor Economics, Vol. 3, Amsterdam, North Holland.

CPB, 1999, WorldScan: the Core version, CPB Special Publication, The Hague.

De Groot H.L.F, G-J Linders, P. Rietveld, and U. Subramanian, 2003, The institutional determinants of bilateral trade patterns, Kyklos 57, 103-123.

De Mooij, R.A., and P.J.G. Tang, 2003, Four Futures of Europe, CPB Special Publication, The Hague.

Dimaranan, B.V. and R.A. McDougall, 2004, Global Trade Assistance and Protection: The GTAP 6 data base (pre release), Centre for Global Trade Analysis, Purdue University, forthcoming.

Dutz, M., M. Us, K. Yilmaz, 2003, Foreign direct investment in Turkey and prospects towards EU accession, mimeo, Undersecretariat of Treasury, Ankara,

http://www.cie.bilkent.edu.tr/papers.html.

Ederveen, S., J. Gorter, R.A. de Mooij and R. Nahuis, Funds and Games: the economics of European cohesion policy, CPB Special Publication, The Hague.

European Commission, 2001, The economic impact of enlargement, Enlargement paper no. 4, DG for Economic and Financial Affairs, Brussels.

European Commission, 2003, Continuing enlargement: strategy paper and Report of the European Commission on the progress towards accession by Bulgaria, Romania and Turkey, Brussels, http://europa.eu.int/comm/enlargement/report_2003/index.htm\#comprehensive.

FIAS Foreign Investment Advisory Service, 2001, Turkey: a diagnostic study of the foreign direct investment environment, a joint service of the International Finance Corporation and The World Bank.

Filiztekin, A., 2000, Openness and productivity growth in Turkish manufacturing, mimeo.

Flam, H., 2003, Turkey and the EU: Politics and economics of accession, CESifo Working Paper no. 893, Munich.

Francois, J., 2003, Accession of Turkey to the EU: implications for the transport sector, mimeo, Tinbergen Institute, http://www.cie.bilkent.edu.tr/papers.html. 
Harrison, G.W., T.F. Rutherford, and D.G. Tarr, 1997, Economic implications of Turkey of a Customs Union with the European Union, European Economic Review 41, p. 861-870.

Lejour, A.M., R.A. de Mooij and R. Nahuis, 2004, EU enlargement: Economic implications for countries and industries, in: H. Berger, T. Moutos and H-W. Sinn (eds), Managing EU enlargement, forthcoming in MIT Press

OECD, 2002, Trends in International Migration, SOPEMI.

Quaisser, W. and A. Reppegather, 2004, EU-beitrittsreife der Turkei und konsequenzen einer EU-Mitgliedschaft, Osteuropa-institut Munich, Working Paper no. 252.

Sak, G., 2000, Characteristics of the fund experience in Turkey: Budgetary funds, extra budgetary funds and other fund-like arrangements, Ankara University, mimeo.

Togan, S., H. Nebioglu, and S.Dogan, 2003, Integration and Manufacturing industry. mimeo, Bilkent University, Ankara, http://www.cie.bilkent.edu.tr/papers.html.

UNCTAD, 2003, World Investment Report, see http://www.unctad.org/wir

World Bank, 2003a, World Development Indicators 2003, Washington.

World Bank, 2003b, Global Development Finance 2003, Washington. 


\section{CESifo Working Paper Series}

(for full list see www.cesifo.de)

1117 Gianmarco I.P. Ottaviano and Giovanni Peri, The Economic Value of Cultural Diversity: Evidence from US Cities, January 2004

1118 Thorvaldur Gylfason, Monetary and Fiscal Management, Finance, and Growth, January 2004

1119 Hans Degryse and Steven Ongena, The Impact of Competition on Bank Orientation and Specialization, January 2004

1120 Piotr Wdowinski, Determinants of Country Beta Risk in Poland, January 2004

1121 Margarita Katsimi and Thomas Moutos, Inequality and Redistribution via the Public Provision of Private Goods, January 2004

1122 Martin Peitz and Patrick Waelbroeck, The Effect of Internet Piracy on CD Sales: CrossSection Evidence, January 2004

1123 Ansgar Belke and Friedrich Schneider, Privatization in Austria: Some Theoretical Reasons and First Results About the Privatization Proceeds, January 2004

1124 Chang Woon Nam and Doina Maria Radulescu, Does Debt Maturity Matter for Investment Decisions?, February 2004

1125 Tomer Blumkin and Efraim Sadka, Minimum Wage with Optimal Income Taxation, February 2004

1126 David Parker, The UK's Privatisation Experiment: The Passage of Time Permits a Sober Assessment, February 2004

1127 Henrik Christoffersen and Martin Paldam, Privatization in Denmark, 1980-2002, February 2004

1128 Gregory S. Amacher, Erkki Koskela and Markku Ollikainen, Deforestation, Production Intensity and Land Use under Insecure Property Rights, February 2004

1129 Yin-Wong Cheung, Javier Gardeazabal, and Jesús Vázquez, Exchange Rate Dynamics: Where is the Saddle Path?, February 2004

1130 Alberto Alesina and Guido Tabellini, Bureaucrats or Politicians?, February 2004

1131 Gregory S. Amacher, Erkki Koskela, and Markku Ollikainen, Socially Optimal Royalty Design and Illegal Logging under Alternative Penalty Schemes, February 2004

1132 David M. Newbery, Privatising Network Industries, February 2004 
1133 Charles Yuji Horioka, The Stagnation of Household Consumption in Japan, February 2004

1134 Eiji Fujii, Exchange Rate Pass-Through in the Deflationary Japan: How Effective is the Yen's Depreciation for Fighting Deflation?, February 2004

1135 Mark M. Spiegel and Nobuyoshi Yamori, Determinants of Voluntary Bank Disclosure: Evidence from Japanese Shinkin Banks, Febrary 2004

1136 Robert Dekle and Kenneth Kletzer, Deposit Insurance, Regulatory Forbearance and Economic Growth: Implications for the Japanese Banking Crisis, February 2004

1137 Takatoshi Ito and Kimie Harada, Bank Fragility in Japan, 1995-2003, February 2004

1138 Kunio Okina and Shigenori Shiratsuka, Policy Duration Effect under Zero Interest Rates: An Application of Wavelet Analysis, February 2004

1139 Francine D. Blau and Lawrence M. Kahn, Do Cognitive Test Scores Explain Higher U.S. Wage Inequality?, February 2004

1140 Michael Rauscher, Economic Growth and Tax-Competing Leviathans, February 2004

1141 Ernst Fehr and Jean-Robert Tyran, Money Illusion and Coordination Failure, February 2004

1142 Ingo Vogelsang, Network Utilities in the U.S. - Sector Reforms without Privatization, March 2004

1143 Marc-Andreas Muendler, Estimating Production Functions When Productivity Change is Endogenous, March 2004

1144 Sascha O. Becker, Samuel Bentolila, Ana Fernandes, and Andrea Ichino, Job Insecurity and Children's Emancipation, March 2004

1145 Pascalis Raimondos-Møller and Alan D. Woodland, Non-Preferential Trading Clubs, March 2004

1146 Robert Fenge and Matthias Wrede, EU Regional Policy: Vertical Fiscal Externalities and Matching Grants, March 2004

1147 Chi-Yung Ng and John Whalley, Geographical Extension of Free Trade Zones as Trade Liberalization: A Numerical Simulation Approach, March 2004

1148 Marc-Andreas Muendler, Trade, Technology, and Productivity: A Study of Brazilian Manufacturers, 1986-1998, March 2004

1149 Eugene Beaulieu, Vivek H. Dehejia, and Hazrat-Omar Zakhilwal, International Trade, Labour Turnover, and the Wage Premium: Testing the Bhagwati-Dehejia Hypothesis for Canada, March 2004 
1150 Giorgio Brunello and Francesca Gambarotto, Agglomeration Effects on EmployerProvided Training: Evidence from the UK, March 2004

1151 S. Brock Blomberg, Gregory D. Hess, and Athanasios Orphanides, The Macroeconomic Consequences of Terrorism, March 2004

1152 Bodo Sturm and Joachim Weimann, Unilateral Emissions Abatement: An Experiment, March 2004

1153 Wolfgang Ochel, Welfare-to-Work Experiences with Specific Work-First Programmes in Selected Countries, March 2004

1154 Jan K. Brueckner and Eric Pels, European Airline Mergers, Alliance Consolidation, and Consumer Welfare, March 2004

1155 Aaron Tornell, Frank Westermann, and Lorenza Martínez, NAFTA and Mexico's Economic Performance, March 2004

1156 George Economides, Sarantis Kalyvitis, and Apostolis Philippopoulos, Do Foreign Aid Transfers Distort Incentives and Hurt Growth? Theory and Evidence from 75 Aidrecipient Countries, March 2004

1157 Robert Fenge and Volker Meier, Are Family Allowances and Fertility-related pensions Siamese Twins?, March 2004

1158 Bruno S. Frey, Simon Luechinger, and Alois Stutzer, Valuing Public Goods: The Life Satisfation Approach, March 2004

1159 Jerome L. Stein and Guay C. Lim, Asian Crises: Theory, Evidence, Warning-Signals, March 2004

1160 Romain Ranciere, Aaron Tornell, and Frank Westermann, Crises and Growth: A ReEvaluation, March 2004

1161 Assaf Razin and Efraim Sadka, Transparency, Specialization and FDI, March 2004

1162 Ludger Woessmann, How Equal Are Educational Opportunities? Family Background and Student Achievement in Europe and the United States, March 2004

1163 B.M.S. van Praag and Barbara E. Baarsma, Using Happiness Surveys to Value Intangibles: The Case of Airport Noise, March 2004

1164 Aaron Tornell, Frank Westermann, and Lorenza Martínez, The Positive Link Between Financial Liberalization, Growth, and Crises, March 2004

1165 Helge Berger and Carsten Hefeker, One Country, One Vote? Labor Market Structure and Voting Rights in the ECB, March 2004

1166 Clemens Fuest and Martin Kolmar, A Theory of User-Fee Competition, March 2004 
1167 Friedrich Schneider and Robert Klinglmair, Shadow Economies around the World: What Do We Know?, April 2004

1168 Horst Raff and Nicolas Schmitt, Exclusive Dealing and Common Agency in International Markets, April 2004

1169 M. Hashem Pesaran and Allan Timmermann, Real Time Econometrics, April 2004

1170 Sean D. Barrett, Privatisation in Ireland, April 2004

1171 V. Anton Muscatelli, Patrizio Tirelli and Carmine Trecroci, Can Fiscal Policy Help Macroeconomic Stabilisation? Evidence from a New Keynesian Model with Liquidity Constraints, April 2004

1172 Bernd Huber and Marco Runkel, Tax Competition, Excludable Public Goods and User Charges, April 2004

1173 John McMillan and Pablo Zoido, How to Subvert Democracy: Montesinos in Peru, April 2004

1174 Theo Eicher and Jong Woo Kang, Trade, Foreign Direct Investment or Acquisition: Optimal Entry Modes for Multinationals, April 2004

1175 Chang Woon Nam and Doina Maria Radulescu, Types of Tax Concessions for Attracting Foreign Direct Investment in Free Economic Zones, April 2004

1176 M. Hashem Pesaran and Andreas Pick, Econometric Issues in the Analysis of Contagion, April 2004

1177 Steinar Holden and Fredrik Wulfsberg, Downward Nominal Wage Rigidity in Europe, April 2004

1178 Stefan Lachenmaier and Ludger Woessmann, Does Innovation Cause Exports? Evidence from Exogenous Innovation Impulses and Obstacles, April 2004

1179 Thiess Buettner and Johannes Rincke, Labor Market Effects of Economic Integration The Impact of Re-Unification in German Border Regions, April 2004

1180 Marko Koethenbuerger, Leviathans, Federal Transfers, and the Cartelization Hypothesis, April 2004

1181 Michael Hoel, Tor Iversen, Tore Nilssen, and Jon Vislie, Genetic Testing and Repulsion from Chance, April 2004

1182 Paul De Grauwe and Gunther Schnabl, Exchange Rate Regimes and Macroeconomic Stability in Central and Eastern Europe, April 2004

1183 Arjan M. Lejour and Ruud A. de Mooij, Turkish Delight - Does Turkey's accession to the EU bring economic benefits?, May 2004 